\title{
Muscoid Diptera as potential vectors of bacterial agents on dairy farms in the northern region of Paraná, Brazil
}

\author{
Dípteros muscóides como potenciais vetores de agentes bacterianos \\ em fazendas de exploração leiteira na região Norte do Paraná, Brasil
}

\author{
Josaine Leila Almeida ${ }^{1 *}$; Rogerio Giuffrida ${ }^{2}$; \\ Ricardo Augusto Pereira Andrade ${ }^{3}$; Marina Platzeck Chaves ${ }^{4}$
}

\begin{abstract}
The aim of this study was to determine the isolation frequency and microbial sensitivity profiles of Escherichia coli, Salmonella spp., and Staphylococcus spp. isolated from synanthropic flies captured in entomological traps placed near the milking parlors of 30 dairy farms located in Northern Paraná, Brazil. In total, 192 flies were captured, and the isolation frequencies of muscids $(21 / 30=70 \%)$ and califorids $(27 / 30=90 \%)$ were significantly higher than that of sarcophagids $(7 / 30=23.3 \%)$. Bacteriological tests on the internal contents and external surfaces of the flies showed that $E$. coli was present only in muscids (14.3\%) and caliphorids (33.3\%). Salmonella spp. was isolated from $9.5 \%$ of the muscids, $7.4 \%$ of the caliphorids, and $14.29 \%$ of the sarcophagids. Staphylococcus spp. was isolated from $28.5 \%$ of the muscids and $29.6 \%$ of the caliphorids. E. coli isolation was more frequent in flies captured on farms at which domestic chickens were housed near the milking parlors $(\mathrm{p}=0.031)$ and which did not use sugarcane for animal feed $(\mathrm{p}=0.042)$. Two out of $27(7.4 \%)$ Staphylococcus spp. strains presented a phenotype of coagulase enzyme production. Ceftriaxone, ciprofloxacin, enrofloxacin, and gentamicin were the most effective antibiotics against E. coli and Salmonella spp. Tetracycline was the least effective antibiotic against the isolates. The Staphylococcus spp. strains isolated did not show the phenotype of oxacillin resistance. We conclude that regional flies are potential mechanical vectors of microbial agents able to cause enteritis in goats, mastitis in cows, and contamination of milk products for human consumption.
\end{abstract}

Key words: Synanthropic flies, dairy cattle, and infectious agents

\section{Resumo}

Moscas sinantrópicas são vetores mecânicos de enfermidades infecciosas para humanos e animais. O presente estudo pretendeu avaliar a presença de Escherichia coli, Salmonella e Staphylococcus spp na população de moscas das famílias Calliphoridae, Muscidae e Sarcophagidae capturadas em 30 fazendas de leite na região Norte do Paraná. As capturas foram realizadas com armadilhas entomológicas contendo iscas a base de fígado bovino, penduradas em árvores próximas as salas de ordenhas das fazendas. Lavados da superfície externa e fluídos extraídos do abdome esmagado das moscas foram semeados em agar sangue ovino a 5\%, agar Mac Conkey e agar Baird-Parker e submetidos a enriquecimento seletivo para Salmonella em caldo Rappaport-Vassiliadis e tetrationato Muller-Kauffmann, seguido de

\footnotetext{
${ }^{1}$ Discente do Programa de Mestrado em Ciência Animal, Universidade do Oeste Paulista, UNOESTE, Presidente Prudente, SP, Brasil. E-mail: josaineleila@hotmail.com

2 Prof., do Programa de Mestrado em Ciência Animal, UNOESTE, Presidente Prudente, SP, Brasil. E-mail: rgiuffrida@unoeste.br

${ }^{3}$ Discente do Programa de Aprimoramento Profissional em Laboratório Veterinário, UNOESTE, Presidente Prudente, SP, Brasil. E-mail: melaogust@ig.com.br

${ }^{4}$ Discente do Curso de Medicina Veterinária, UNOESTE, Presidente Prudente, SP, Brasil. E-mail: mari platzeck@hotmail.com

* Author for correspondence
} 
plaqueamento em agar Xilose Lisina Desoxicolato (XLD) e agar Salmonella-Shigella. Os microrganismos isolados foram classificados bioquimicamente. Foram capturadas 192 moscas pertencentes às famílias Muscidae, Calliphoridae e Sarcophagidae. Nas fazendas pesquisadas, as capturas de Muscidae (21/30 $=70 \%)$ e Calliphoridae $(27 / 30=90 \%)$ foram mais frequentes do que as capturas de Sarcophagidae $(7 / 30=23,3 \%)$. E. coli foi isolada apenas de muscídeos $(14,3 \%)$ e califorídeos $(33,3 \%)$. Salmonella foi isolada de 9,5\% dos muscídeos, 7,4\% dos califorídeos e de 14,29\% dos sarcofagídeos capturados. Staphylococcus spp foi isolado de $28,5 \%$ dos muscídeos e $29,6 \%$ dos califorídeos. Os isolamentos de $E$. coli foram mais comuns e moscas capturadas em fazendas que mantinham criações de aves próximas ao local $(\mathrm{p}=0,031)$ de ordenha e que não utilizavam cana-de-açúcar para alimentação dos animais $(\mathrm{p}=0,042)$. Conclui-se que as moscas presentes em fazendas de leite da região apresentam grande importância sanitária, visto que os agentes isolados são capazes de causar enterites em bezerros, mastites nas vacas e contaminação de produtos lácteos produzidos no local.

Palavras-chave: Moscas sinantrópicas, bovinocultura de leite, agentes infecciosos, Norte Pioneiro do Paraná

\section{Introduction}

Non-hematophagous synanthropic flies belong to the order Diptera, and are known to be mechanical vectors that carry infectious and parasitic diseases to human and animals. These insects carry pathogenic microbial agents from contaminated organic substrates that they use for reproduction and feeding, especially feces from livestock and decaying organic matter (LEVINE; LEVINE, 1991). The flies most likely to cause sanitation issues belong to the families Sarcophagidae (sarcophagus flies), Muscidae (house flies), and Calliphoridae (blow flies) (GRACZYK et. al., 2001), which are distinct in the substrates they use for reproduction and in their synanthropic habits. Several pathogenic microorganisms are frequently isolated from these Diptera, especially Salmonella spp., Yersinia enterocolitica, Edwardsiella tarda, Shigella sonnei, Escherichia coli, Klebsiella spp., methicillinresistant Staphylococcus aureus, Pseudomonas aeruginosa, and Enterococcus faecalis (RAHUMA et al., 2005).

On dairy farms, synanthropic flies may transmit microbial agents related to several conditions, such as enteritis, mastitis, and dermatitis, to animals (BRAVERMAN et al., 1999; FÖRSTER et al., 2009). Some species are known to be vectors of bacterial pathogens associated with bovine mastitis, an infection of the mammary glands that results in reduced milk production and increased somatic cell counts, with important effects on public health (OLIVER et al., 2005). In locations with high rates of infestation, the flies can also transfer infectious agents to milk products, such as fresh cheese (CARDOZO et al., 2009).

The aim of this study was to evaluate the microbial sensitivity and the isolation frequency of Escherichia coli, Salmonella spp., and Staphylococcus spp. isolated from washed surfaces and the internal contents of synanthropic flies captured on 30 farms in the northern region of Paraná and to evaluate the risk factors associated with the isolation of these microorganisms.

\section{Material and Methods}

The study was performed between February and March 2011 on dairy farms located in the municipalities of Andirá (latitude $23^{\circ} 03^{\prime}$, longitude $50^{\circ} 13^{\prime}$, altitude of $470 \mathrm{~m}$ ), Bandeirantes (latitude $23^{\circ} 06^{\prime}$, longitude $50^{\circ} 22^{\prime}$, altitude of $420 \mathrm{~m}$ ), and Abatiá (latitude $23^{\circ} 18^{\prime}$, longitude $50^{\circ} 18^{\prime}$, altitude of $620 \mathrm{~m}$ ), in the northern region of the state of Paraná, Brazil. Thirty farms were randomly selected from a total of 42 farms participating in projects for the technological development of the dairies that produce commercial milk products in the region.

For fly capture, entomological traps built from 2-L plastic bottles were used, adapting a methodology described by Dias et al. (2009). Each trap was built 
using two bottles, with the bottoms removed to allow one to fit inside the other. The bottle on the inside was painted black and the one on the outside was left transparent. Before being used, the traps were disinfected with $70 \%$ ethanol. Each trap was then hung from a tree at a minimum distance of 20 $\mathrm{m}$ from the milking parlors and at a height of 1.0$1.70 \mathrm{~m}$ above the ground. Inside each trap, $10 \mathrm{~g}$ of bovine liver was attached to a metallic hook as bait. Flies entered the trap from the below landed on the bait, and then proceeded in the direction of the light, where they were caught in the transparent bottle. After $24 \mathrm{~h}$ at the collection points, the traps were removed, sealed with tape, placed in refrigerated isothermal boxes and transported to laboratories for performance of microbiological tests in less than 4 hours.

During fly capture, a structured questionnaire composed of closed questions that had been previously tested was given to the employees or the owners responsible for handling the milking, with the purpose of collecting epidemiological information associated with the presence of insects on the property. The questionnaire included questions concerning poultry and swine husbandry on the farm, the use of lay stalls for disposal of animal waste, the manner of milking, the alimentary supplements offered in troughs (ground sugarcane and concentrates), and the control of rodents.

The captured flies were inactivated in a freezer at $-12{ }^{\circ} \mathrm{C}$ for $30 \mathrm{~min}$ and identified with the aid of a stereoscopic microscope using taxonomic keys specific for each family (CARVALHO; MELLOPATIU, 2008) For each farm, the flies belonging to the families Muscidae, Calliphoridae, and Sarcophagidae were divided into separate sterile containers. Between one and five samples from each family were randomly selected from each container to undergo bacteriological tests.

Separate bacteriological tests were performed on the internal and external portions of the fly body. External samples were obtained by washing the captured exemplars in $3 \mathrm{~mL}$ of sterile physiological solution in $5-\mathrm{mL}$ glass tubes, using a vortexer. To collect the contents of midgut and hindgut, the captured insects were first washed in $70 \%$ ethanol for $5 \mathrm{~min}$ for superficial disinfection. The insects were then washed with sterile physiological solution to remove any remaining traces of ethanol. The washed flies were placed in sterile tubes with $3 \mathrm{~mL}$ sterile physiological solution, and the abdomen and cephalothorax were crushed using sterile forceps, followed by vortexing of the tubes.

The fluids obtained from the internal and the external parts of the flies were separately cultured on $5 \%$ bovine blood agar and Baird-Parker agar supplemented with egg yolk and potassium telluride for the isolation of Staphylococcus aureus and MacConkey agar for the isolation of enterobacteria. After 24-48 hours of incubation at $35^{\circ} \mathrm{C}$, the microorganisms isolated on the plates were identified using Gram staining and morphological and biochemical characteristics (MURRAY et al., 2003). For the isolation of Salmonella, $0.1 \mathrm{~mL}$ fluid was removed from each inoculum for culture in tubes containing Rappaport-Vassiliadis broth, and $1 \mathrm{~mL}$ was removed for culture in tubes containing Muller-Kauffmann tetrathionate broth. The cultures were incubated at $35^{\circ} \mathrm{C}\left( \pm 1^{\circ} \mathrm{C}\right)$ for $18 \mathrm{~h}$ and then plated on xylose lysine desoxycholate (XLD) agar and Salmonella-Shigella agar. The plates were incubated for $24-48$ hours at $37^{\circ} \mathrm{C}$. The isolated microorganisms were identified using Gram staining and morphological and biochemical characteristics, as well as their reactivity in a serodiagnostic test using anti-Salmonella polyvalent serum (Probac $\AA$ ).

The microbial sensitivity of the isolates was determined using the classic method of disk diffusion. Bacterial inocula grown on brain-heart infusion broth in a final volume of $0.1 \mathrm{~mL}$, corresponding to 0.5 on the MacFarland turbidity scale, were spread over the surface of plates containing MuellerHinton agar. Filter paper discs impregnated with the antibiotics ampicillin (10 mcg), ceftriaxone (30 mcg), ciprofloxacin (5 mcg), enrofloxacin (5 
mcg), gentamicin (10 mcg), sulfamethoxazol + trimethoprim $(25 \mathrm{mcg})$, and tetracycline $(30 \mathrm{mcg})$ were then added to the surface of the agar. Paper discs containing cefalexin (30 mcg), oxacillin (1 mcg), and penicillin G (10 UI) were used for Staphylococcus spp. strains. After incubation of the plates at $37^{\circ} \mathrm{C}$ for $24 \mathrm{~h}$, the microorganisms' growth inhibition halos were compared with the accepted standards for classification and classified as sensitive, partially sensitive, or resistant. (NCCLS, 2005).

To determinate whether the capture frequencies differed between flies in the families Muscidae, Calliphoridae, and Sarcophagidae, Fisher's exact test was used. The same test was used to analyze whether the isolation frequency of E. coli, Salmonella spp., and Staphylococcus spp. differed between the fly families. To evaluate the correlations between the isolation rates of the various fly families and the information collected using the epidemiological questionnaires, Fisher's exact test was used. For all analyses, a $P$-value $<0.05$ was considered statistically significant (PAGANO; GAUVREAU, 2004).

\section{Results}

At the time of fly capture, each farm housed an average of 34.7 bovines (range: 9-93), including both calves and adults, with an average production of 90.7 L of milk per farm and 9.36 L per lactating animal. In total, 192 flies were captured, of which 114 belonged to the family Calliphoridae, 64 to Muscidae, and 14 to Sarcophagidae. The capture of flies belonging to Calliphoridae was observed on 27 farms (90\%), Muscidae on 21 farms (70\%), and Sarcophagidae on 7 farms (23.2\%). Muscids and caliphorids were captured significantly more frequently than sarcophagids $(P<0.05)$.

A total of 12 E. coli strains were isolated. At 3 of the $21(14.3 \%)$ farms, flies of the family Muscidae were captured, and E. coli was isolated from external surface samples or internal abdomen contents from these flies. In contrast, E. coli was isolated from flies of the family Calliphoridae at only 7 of the 27 (33.3\%) farms evaluated, and was never isolated from flies of the Sarcophagidae family (Table 1). The frequencies of $E$. coli isolation did not differ between the families Calliphoridae and Muscidae $(P=0.2396)$. E. coli was isolated more frequently from flies captured on farms with domestic chickens $(P=0.031)$ and those not providing sugarcane in the animal troughs $(P=0.042)$.

Table 1. Pathogenic microorganisms isolated from the external surface and internal contents of synanthropic flies captured near the milking parlors of dairy farms in the northern region of Paraná, 2012 ( $n=30)$.

\begin{tabular}{lcccc}
\hline \multirow{3}{*}{ Family } & & \multicolumn{3}{c}{ Microorganism } \\
\cline { 3 - 4 } Muscidae & External & Escherichia coli & Salmonella spp & Staphylococcus spp \\
& Internal & $2 / 21(9,5 \%)$ & $1 / 21(4,7 \%)$ & $6 / 21(28,5 \%)$ \\
& Total & $3 / 21(4,7 \%)$ & $2 / 21(9,5 \%)$ & $0 / 21(0 \%)$ \\
\multirow{3}{*}{ Calliphoridae } & External & $6 / 27(22,2 \%)$ & $2 / 21(9,5 \%)$ & $6 / 21(28,5 \%)$ \\
& Internal & $6 / 27(22,2 \%)$ & $1 / 27(3,7 \%)$ & $8 / 27(29,6 \%)$ \\
& Total & $9 / 27(33,3 \%)$ & $1 / 27(3,7 \%)$ & $0 / 27(0 \%)$ \\
Sarcophagidae & $2 / 27(7,4 \%)$ & $8 / 27(29,6 \%)$ \\
& External & $0 / 7(0 \%)$ & $0 / 7(0 \%)$ & $0 / 7(0 \%)$ \\
& Internal & $0 / 7(0 \%)$ & $1 / 7(14,29 \%)$ & $0 / 7(0 \%)$ \\
& Total & $0 / 7(0 \%)$ & $1 / 7(14,29 \%)$ & $0 / 7(0 \%)$ \\
\hline
\end{tabular}

Source: Elaboration of the authors. 
In total, 8 Salmonella spp. strains were isolated. The isolates were obtained from flies from all three families evaluated, from both external and internal samples, from between 0 and $14.1 \%$ of the farms on which the flies were captured (Table 1). The isolation frequency did not differ among the three families $(P=0.8496)$. Salmonella was isolated less frequently from flies captured on farms that kept domestic poultry $(P=0.041)$.
Twenty-seven Staphylococcus spp. strains were isolated from flies captured at 17 of the 30 evaluated farms $(56.66 \%)$, and production of coagulase enzyme was observed in 2 isolates (7.4\%). The strains were isolated from external samples of muscids and caliphorids in $28.5 \%(6 / 21)$ and $29.6 \%$ $(8 / 27)$ of the farms, respectively (Table 1$)$. Isolation of Staphylococcus was not significantly correlated with any of the risk factors examined (Table 2).

Table 2. Risk factors associated with the capture of synanthropic flies with positive isolations of Escherichia coli, Salmonella, and Staphylococcus spp. on dairy farms in the northern region of Paraná, $2012(n=30)$.

\begin{tabular}{|c|c|c|c|c|c|c|c|c|c|}
\hline \multirow{3}{*}{ Variable } & \multicolumn{9}{|c|}{ Microrganism } \\
\hline & \multicolumn{3}{|c|}{ E.coli } & \multicolumn{3}{|c|}{ Salmonella } & \multicolumn{3}{|c|}{ Staphylococcus } \\
\hline & Pos & Neg & $\mathrm{P}$ & Pos & neg & $\mathrm{p}$ & pos & neg & $\mathrm{p}$ \\
\hline \multicolumn{10}{|l|}{$\begin{array}{l}\text { Poultry husbandry } \\
\text { on the farm }\end{array}$} \\
\hline Yes & $\begin{array}{c}12 \\
(40 \%)\end{array}$ & $\begin{array}{c}12 \\
(40 \%)\end{array}$ & \multirow{2}{*}{$0,031^{*}$} & $2(6,7 \%)$ & $\begin{array}{c}22 \\
(73,3 \%)\end{array}$ & \multirow{2}{*}{$0,041^{*}$} & $\begin{array}{c}13 \\
(43,3 \%)\end{array}$ & $\begin{array}{c}11 \\
(36,7 \%)\end{array}$ & \multirow{2}{*}{0,470} \\
\hline No & $\begin{array}{c}0 \\
(0 \%)\end{array}$ & $\begin{array}{c}6 \\
(20 \%)\end{array}$ & & $\begin{array}{c}3 \\
(10 \%)\end{array}$ & $\begin{array}{c}3 \\
(10 \%)\end{array}$ & & $\begin{array}{c}4 \\
(13,3 \%)\end{array}$ & $\begin{array}{c}2 \\
(6,7 \%)\end{array}$ & \\
\hline \multicolumn{10}{|l|}{$\begin{array}{l}\text { Swine husbandry } \\
\text { on the farm }\end{array}$} \\
\hline Yes & $\begin{array}{c}6 \\
(20 \%)\end{array}$ & $\begin{array}{c}5 \\
(16,7 \%)\end{array}$ & \multirow{2}{*}{0,197} & $1(3,3 \%)$ & $\begin{array}{c}10 \\
(33,3 \%)\end{array}$ & \multirow{2}{*}{0,381} & $\begin{array}{c}7 \\
(23,3 \%)\end{array}$ & $\begin{array}{c}4 \\
(13,3 \%)\end{array}$ & \multirow{2}{*}{0,421} \\
\hline No & $\begin{array}{c}6 \\
(20 \%)\end{array}$ & $\begin{array}{c}13 \\
(43,3 \%)\end{array}$ & & $\begin{array}{c}4 \\
(13,3 \%)\end{array}$ & $15(50 \%)$ & & $\begin{array}{c}10 \\
(33,3 \%)\end{array}$ & $\begin{array}{c}9 \\
(30 \%)\end{array}$ & \\
\hline \multicolumn{10}{|l|}{$\begin{array}{l}\text { Use of lay stalls for } \\
\text { disposal of animal } \\
\text { waste }\end{array}$} \\
\hline Yes & $\begin{array}{c}12 \\
(40 \%)\end{array}$ & $\begin{array}{c}14 \\
(46,7 \%)\end{array}$ & \multirow{2}{*}{0,112} & $\begin{array}{c}5 \\
(16,7 \%)\end{array}$ & $21(70 \%)$ & \multirow{2}{*}{0,462} & $\begin{array}{c}13 \\
(43,3 \%)\end{array}$ & $\begin{array}{c}13 \\
(43,3 \%)\end{array}$ & \multirow{2}{*}{0,087} \\
\hline No & $\begin{array}{c}0 \\
(0 \%)\end{array}$ & $\begin{array}{c}4 \\
(13,3 \%)\end{array}$ & & $\begin{array}{c}0 \\
(0 \%)\end{array}$ & $4(13,3 \%)$ & & $\begin{array}{c}4 \\
(13,3 \%)\end{array}$ & $\begin{array}{c}0 \\
(0 \%)\end{array}$ & \\
\hline \multicolumn{10}{|l|}{ Manner of milking } \\
\hline Manual & $\begin{array}{c}9 \\
(30 \%)\end{array}$ & $\begin{array}{c}16 \\
(53,3 \%)\end{array}$ & \multirow{2}{*}{0,304} & $\begin{array}{c}4 \\
(13,3 \%)\end{array}$ & $21(70 \%)$ & \multirow{2}{*}{0,627} & $\begin{array}{c}14 \\
(46,7 \%)\end{array}$ & $\begin{array}{c}11 \\
(36,7 \%)\end{array}$ & \multirow{2}{*}{0,633} \\
\hline Mechanical & $\begin{array}{c}3 \\
(10 \%)\end{array}$ & $\begin{array}{c}2 \\
(6,7 \%)\end{array}$ & & $1(3,3 \%)$ & $4(13,3 \%)$ & & $\begin{array}{c}3 \\
(10 \%)\end{array}$ & $\begin{array}{c}2 \\
(6,7 \%)\end{array}$ & \\
\hline \multicolumn{10}{|l|}{$\begin{array}{l}\text { Ground sugarcane } \\
\text { offered in troughs }\end{array}$} \\
\hline Yes & $4(13,3 \%)$ & $\begin{array}{c}13 \\
(43,3 \%)\end{array}$ & \multirow{2}{*}{$0,042^{*}$} & $2(6,7 \%)$ & $15(50 \%)$ & \multirow{2}{*}{0,367} & $\begin{array}{c}12 \\
(40 \%)\end{array}$ & $\begin{array}{c}5 \\
(16,7 \%)\end{array}$ & \multirow{2}{*}{0,082} \\
\hline No & $8(26,7 \%)$ & $\begin{array}{c}5 \\
(16,7 \%)\end{array}$ & & $\begin{array}{c}3 \\
(10 \%)\end{array}$ & $\begin{array}{c}10 \\
(33,3 \%)\end{array}$ & & $\begin{array}{c}5 \\
(16,7 \%)\end{array}$ & $\begin{array}{c}8 \\
(26,7 \%)\end{array}$ & \\
\hline
\end{tabular}


continuação

Concentrates

offered in troughs

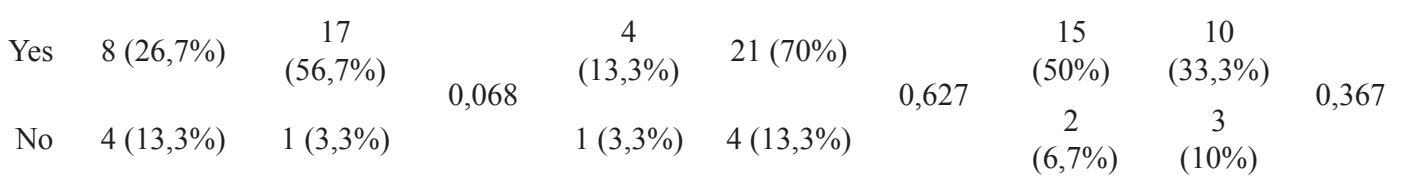

Control of rodents

\begin{tabular}{|c|c|c|c|c|c|c|c|c|c|}
\hline Yes & $\begin{array}{c}9 \\
(30 \%)\end{array}$ & $\begin{array}{c}14 \\
(46,7 \%)\end{array}$ & 507 & $\begin{array}{c}3 \\
(10 \%)\end{array}$ & $\begin{array}{c}20 \\
(66,7 \%)\end{array}$ & 0320 & $\begin{array}{c}10 \\
(33,3 \%)\end{array}$ & $\begin{array}{c}13 \\
(43,3 \%)\end{array}$ & 0660 \\
\hline No & $\begin{array}{c}3 \\
(10 \%)\end{array}$ & $\begin{array}{c}4 \\
(13,3 \%)\end{array}$ & ונד, & $2(6,7 \%)$ & $5(16,7 \%)$ & (3) & $\begin{array}{c}3 \\
(10 \%)\end{array}$ & $\begin{array}{c}4 \\
(13,3 \%)\end{array}$ & 0,000 \\
\hline
\end{tabular}

$* p<0,05 ; \operatorname{pos}=$ positive isolation; neg $=$ negative isolation; $p=$ statistical significance.

Source: Elaboration of the authors.

The results of the sensitivity profiles of the isolates are summarized in Table 3. The most effective antibiotics against gram-negative microbes were ceftriaxone, ciprofloxacin, enrofloxacin, gentamicin, and sulfazotrim, whereas ampicillin and tetracycline were the least effective. All the antibiotics tested were effective against Staphylococcus spp. (Table 3).

Table 3. Percentage of sensitive (Sens), partially sensitive (Parc), or resistant (Res) microorganisms isolated from synanthropic flies captured in dairy farms in the northern region of Paraná, $2012(\mathrm{n}=30)$.

\begin{tabular}{|c|c|c|c|c|c|c|}
\hline \multirow{3}{*}{$\begin{array}{c}\text { Antimicrobial } \\
\text { agente }\end{array}$} & \multicolumn{6}{|c|}{ Microrganism } \\
\hline & \multicolumn{2}{|c|}{ E. coli $(\mathrm{N}=12)$} & \multicolumn{2}{|c|}{ Salmonella $\operatorname{spp}(\mathrm{N}=8)$} & \multicolumn{2}{|c|}{ Staphylococcus $\operatorname{spp}(\mathrm{N}=27)$} \\
\hline & Sens & Parc/Res & Sens & Parc/Res & Sens & Parc/Res \\
\hline Ampicillin & $4 / 12(33,3 \%)$ & $8 / 12(66,7 \%)$ & $5 / 8(62,5 \%)$ & $3 / 8(37,5 \%)$ & $23 / 27(85,19 \%)$ & $4 / 27(14,81 \%)$ \\
\hline Cephalexin* & - & - & - & - & $25 / 27(92,59 \%)$ & $2 / 27(7,41 \%)$ \\
\hline Ceftriaxone & $12 / 12(100 \%)$ & $0 / 12(0 \%)$ & $8 / 8(100 \%)$ & $0 / 8(0 \%)$ & $24 / 27(88,89 \%)$ & $3 / 27(11,11 \%)$ \\
\hline Ciprofloxacin & $12 / 12(100 \%)$ & $0 / 12(0 \%)$ & $6 / 8(75,0 \%)$ & $2 / 8(25,0 \%)$ & $26 / 27(96,27 \%)$ & $1 / 27(3,70 \%)$ \\
\hline Enrofloxacin & $12 / 12(100 \%)$ & $0 / 12(0 \%)$ & $6 / 8(75,0 \%)$ & $2 / 8(25,0 \%)$ & $22 / 27(81,48 \%)$ & $5 / 27(18,52 \%)$ \\
\hline Gentamicin & $12 / 12(100 \%)$ & $0 / 12(0 \%)$ & $6 / 8(75,0 \%)$ & $2 / 8(25,0 \%)$ & $27 / 27(100,00 \%)$ & $0 / 27(0,00 \%)$ \\
\hline Oxacillin* & - & - & - & - & $27 / 27(100,00 \%)$ & $0 / 27(0,00 \%)$ \\
\hline Penicillin $\mathrm{G}^{*}$ & - & - & - & - & $19 / 27(70,37 \%)$ & $8 / 27(29,63 \%)$ \\
\hline Sulphazotrin & $10 / 12(83,3 \%)$ & $2 / 12(16,7 \%)$ & $6 / 8(75,0 \%)$ & $2 / 8(25,0 \%)$ & $27 / 27(100,00 \%)$ & $0 / 27(0,00 \%)$ \\
\hline Tetracycline & $6 / 12(50,0 \%)$ & $6 / 12(50,0 \%)$ & $0 / 8(0 \%)$ & $8 / 8(100 \%)$ & $19 / 27(70,37 \%)$ & $8 / 27(29,63 \%)$ \\
\hline
\end{tabular}

* Evaluated only for Staphylococcus spp.

Source: Elaboration of the authors.

\section{Discussion}

Capturing flies in baited traps is a method frequently used to estimate the density of these insects in several types of environments (FERREIRA; LACERDA, 1993; DIAS et al., 2009). The capture proportions observed in the traps set at the 30 farms are expected to reflect the fly populations associated with the conditions present in and around the milking parlors. The insects take shelter in the parlors during the hottest hours of the day, interacting with attractive substrates, such as animal excretions, feed remnants, and milk 
residues (GERRY et al., 2011). The milking parlors present unavoidably precarious sanitary conditions, since a considerable amount of fresh feces are deposited there each day, hampering the control of fly populations and favoring the dispersion of insects to houses in urban and proximal rural zones (HOGSETTE et al., 2012).

We observed more flies from the families Muscidae and Calliphoridae than the family Sarcophagidae. These results differ from those of other studies describing the predominance of sarcophagid flies compared to muscid flies in rural areas of the state of Rio de Janeiro (MACEDO et al., 2011). The prevalence of Calliphoridae and Muscidae in the regions analyzed may be attributed to the greater adaptability of species, such as $C$. megacephala and M. domestica to the environmental conditions of tropical and subtropical regions and to their ability to proliferate in diverse trophic niches, compared to sarcophagids (PARALUPPI; CASTELLÓN, 1994). Moreover, the caliphorids, the group most frequently captured in the traps used, present a high invasive potential in anthropic and natural environments, where they prevail over indigenous flies (REIS et al., 1996).

E. coli, a microorganism typically found in feces, was isolated from muscids and caliphorids, possibility due to the coprophilic habits of these animals. E. coli was found in isolates from the exoskeleton and the internal contents of the flies, concordant with the results of other studies (FÖRSTER et al., 2009; BOUAMAMAA et al., 2010). These observations demonstrate the ability of flies to carry fecal bacteria with pathogenic potential to human beings and animals, especially in regards to highly endophilic flies frequently observed inside houses containing substrates and organic residues produced by human activity (EESA; EL-SIBAE, 1993).

Three relevant aspects concerning the isolation of E. coli should be emphasized. The first is related to the potential of the flies to transmit enterotoxigenic strains of $E$. coli to newborn calves. Transmission can occur when the flies come in contact with feces from young and adult animals that asymptomatically excrete enteropathogenic E. coli strains (DE RYCKE et al., 1986) and carry them to anatomic regions such as the udders of lactating cows, infecting nursing calves. A second important aspect is related to coliform mastitis, an acute condition with systemic effects caused by absorption of bacterial endotoxins (BURVENICH et al., 2003). Flies exposed to an environment containing $E$. coli can become colonized with the bacteria and might serve as a source for transmission of environmental mastitis to milk cows. The third aspect that we would like to highlight is associated with the possibility that flies carry fecal coliform bacteria to the milk produced on the farm. In $83.3 \%$ of the farms evaluated, milking was performed manually, a procedure that allows contact between the milk and flies present in the milking parlor. Milk sterilization methods are sufficient to kill the microorganism, but the bacteria might survive in raw milk and contaminate homemade fresh cheese (QUINTO; CEPEDA, 1997).

E. coli was isolated more frequently from flies captured from farms that kept poultry or broilers, often free, near the milking parlors. These results suggest that flies are attracted by the excrement deposited on the ground by the domestic chickens. These observations are consistent with other studies, suggesting that fresh chicken is a resource frequently used by flies for reproduction (MOON et al., 2001). E. coli was isolated less frequently from flies of the family Muscidae captured on farms that used sugarcane in animal troughs, compared to those that did not offer this food. These results suggest that sugarcane may influence the habits of the flies in regards to the search for substrates, and the resulting potential fecal contamination of the insects, since the profile of the pathogenic microorganisms carried by the flies depends, in part, on the type of substrate they utilize for nourishment or egg deposition. In the absence of a preferential 
substrate, the flies search for alternative substrates (D’ALMEIDA; MELLO, 1996). Moreover, adult flies can retain pathogenic bacteria acquired in the larval phase (SCHUSTER et al., 2013).

Salmonella was isolated from flies belonging to all three families analyzed, most commonly from sarcophagids. The isolation proportions were similar to those described by Choo et al. (2011) in Malaysia. However, on the farms evaluated, no animals with enteric symptoms typical of salmonellosis were observed. Therefore, the isolation of Salmonella may have resulted from contact of the flies with feces from carrier animals that asymptomatically excrete the bacteria, a very common situation in bovines infected by Salmonella (MOHLER; IZZO; HOUSE, 2009), or from other extra-fecal sources (PRADHAN et al., 2009). Salmonella cannot survive in the flies for prolonged periods, and therefore it can only remain present in the insect populations if they re-contaminate themselves every few hours (HOLT et al., 2007).

Contrary to the results observed for E. coli, Salmonella was isolated less frequently from flies captured on farms that kept poultry or broilers near the milking parlors. These results contradict those of other studies, which have shown that flies that cohabitate with poultry are more prone to infection by Salmonella (HOLT et al., 2007).

Similar to E. coli, Salmonella can be transmitted by synanthropic flies to calves, cause mastitis in cows, and contaminate milk products made from raw milk. In addition, the flies may disperse this agent to food produced in nearby areas, such as rural communities and neighboring properties, and cause salmonellosis outbreaks in humans. Adequate control of fly populations can reduce the number of cases of diarrhea in humans in exposed areas by $23 \%$ (CHAVASSE et al., 1999).

Staphylococcus was isolated from the external surfaces of muscid and calliphorid flies. Of the 27 isolates of Staphylococcus, 2 (7.1\%) were found to be producers of coagulase, the main virulence marker for the genus, which is associated with cases of infectious mastitis in milk cows (SILVA; SILVA, 2005). The results observed are consistent with those of other studies demonstrating that the family Muscidae is able to carry both coagulasepositive and -negative Staphylococcus species (BOUAMAMAA et al., 2010).

The absence of Staphylococcus from the internal contents of the flies may be due to the secretion of peptides with antimicrobial effects in the digestive tract of the insects, which limit bacterial survival (NAYDUCH; CHO; JOYNER, 2013). Therefore, this microorganism presents a higher probability of transmission following superficial contact with the insects than with their feces or digestive juices. Considering that coagulase-negative Staphylococcus species are considered to be emergent mammalian pathogens (DUFOUR et al., 2012), these results emphasize the importance of muscoid Diptera as potential mechanical vectors of staphylococcus mastitis among milk cows, possibly involving transmission mechanisms similar to those observed in cases of summer mastitis caused by Arcanobacterium pyogenes (BRAMLEY et al., 1985), in which the pus-containing milk is attractive to flies, which then becomes externally contaminated.

Ampicillin and tetracycline were the least effective antibiotics against E.coli and Salmonella spp. Resistance to these antibiotics has been observed in other studies of gram-negative microbial agents isolated from synanthropic flies (BOUAMAMAA et al., 2010), and is considered relatively common in enterobacteria isolated from bovine fecal samples (SAWANT et al., 2007), possibly due to the selection pressure arising from the massive, abusive, and unsupported use of sensitivity tests in livestock (TURNIDGE, 2004). Quinolones (enrofloxacin and ciprofloxacin), gentamicin, and ceftriaxone were the most effective antibiotics against the gramnegative agents isolated, consistent with the results of similar studies (BOUAMAMAA et al., 2010). Therefore, it is recommended that the dairy farms 
utilize these antibiotics and derivatives of the same pharmacological line in a sensate and controlled manner, with the aim of reducing selection pressure and the transmission of resistant pathogenic agents to synanthropic Diptera, since exchange of mobile genetic elements encoding antimicrobial resistance may occur in the digestive tract of these insects (AKHTAR; HIRT; ZUREK, 2009).

More than $70 \%$ of the Staphylococcus spp. strains showed resistance to the tested antibiotics. The least effective drugs against these agents were penicillin $\mathrm{G}$ and tetracycline, whereas the most effective was sulfamethoxazol in association with trimethoprim, oxacillin, and gentamicin. The high effectiveness of the tested antibiotics against the agent may be related to the elevated percentage of isolates classified as coagulase-negative, considering that some researchers have reported that strains of this agent isolated from bovines showed resistance less frequently than coagulase-positive species. On the other hand, these agents are known to be emergent mammalian pathogens, and the frequent use of antibiotics against mastitis may cause the emergence of multidrug-resistant strains of coagulase-negative Staphylococcus (DELLA LIBERA et al., 2010).

\section{Conclusions}

Synanthropic flies are potential vectors of Salmonella spp., E. coli, and Staphylococcus spp., bacterial agents associated with mastitis and enteritis in milk cows and with food contamination. Attractants associated with faming nearthe milking parlors may have influenced the population dynamics of muscoid Diptera on the farms studied here.

\section{References}

ABU-RAYYAN, A. M.; ABU-IRMAILEH, B. E.; AKKAWI, M. M. Manure composting reduces house fly population. Journal of Agricultural Safety and Health, St. Joseph, v. 16, n. 2, p. 99-110, 2010.
AKHTAR, M.; HIRT, H.; ZUREK, L. Horizontal transfer of the tetracycline resistance gene tetM mediated by pCF10 among Enterococcus faecalis in the house fly (Musca domestica L.) alimentary canal. Microbial Ecology, New York, v. 58, n. 3, p. 509-518, 2009.

BOUAMAMAA, L.; SORLOZANO, A.; LAGLAOUI, A.; LEBBADI, M.; AARAB, A.; GUTIERREZ, J. Antibiotic resistance patterns of bacterial strains isolated from Periplaneta americana and Musca domestica in Tangier, Morocco. The Journal of Infection in Developing Contries, v. 4, n. 4, p. 194-201, 2010.

BRAMLEY, A. J.; HILlERTON, J. E.; HIGGS, T. M.; HOGBEN, E. M. The carriage of summer mastitis pathogens by muscid flies. British Veterinary Journal, London, v. 141, n. 6, p. 618-627, 1985.

BRAVERMAN, Y.; CHIZOV-GINZBURG, A.; SARAN, A.; WINKLER, M. The role of houseflies (Musca domestica) in harbouring Corynebacterium pseudotuberculosis in dairy herds in Israel. Revue Scientifique et Technique, Paris, v. 18, n. 3, p. 681-90, 1999.

BURVENICH, C.; VAN MERRIS, V.; MEHRZAD, J.; DIEZ-FRAILE, A; DUCHATEAU, L. Severity of E. coli mastitis is mainly determined by cow factors. Veerinary Research, Paris, v. 34, n. 5, p. 521-564, 2003.

CARDOZO, G. M. B. Q.; MORENO, I.; VAN DENDER, A. G. F.; TRENTO, F. K. H. S. Musca domestica como vetor de microrganismos patogênicos para queijo Minas Frescal Ultrafiltrado. Brazilian Journal of Food Technology, São Paulo, v. 12, n. 2, p. 85-91, 2009.

CARVALHO, C. J. B. de; MELLO-PATIU, C. A. deDE. Key to the adults of the most common forensic species of Diptera in South America. Revista Brasileira de Entomologia, São Paulo, v. 52, n. 3, p. 390-406, 2008.

CHAVASSE, D. C.; SHIER R. P.; MURPHY, O. A.; HUTTLY, S. R.; COUSENS, S. N.; AKHTAR T. Impact of fly control on childhood diarrhoea in Pakistan: community-randomised trial. Lancet, London, v. 353, n. 9146, p. 2-5, 1999.

CHOO, L. C.; SALEHA, A. A.; WAI, S. S.; FAUZIAH, N. Isolation of Campylobacter and Salmonella from houseflies (Musca domestica) in a university campus and a poultry farm in Selangor, Malaysia. Tropical Biomedicine, Kuala Lumpur, v. 28, n. 1, p. 16-20, 2011.

D'ALMEIDA, J. M.; MELLO, R. P. Comportamento de dípteros muscóides frente a substratos de oviposição, em laboratório, no Rio de Janeiro, RJ, Brasil. Memórias do Instituto Oswaldo Cruz, Rio de Janeiro, v. 91, n. 1, p. 131-136, 1996. 
DELLA LIBERA, A. M. M. P.; BLAGITZ, M. G.; SOUZA, F. N.; BATISTA, C. F.; AZEDO, M. R.; BENITES, N. R.; MELVILlE, P. A.; GOMES, V. Antimicrobial susceptibility of coagulase-negative staphylococci isolated from meat-producing ewes with mastitis. Arquivo Brasileiro de Medicina Veterinária e Zootecnia, Belo Horizonte, v. 62, n. 6, p. 1499-1502, 2010.

DE RYCKE, J.; BERNARD, S.; LAPORTE, J.; NACIRI, M.; POPOFF, M. R.; RODOLAKIS, A. Prevalence of various enteropathogens in the feces of diarrheic and healthy calves. Ann Rech Vet, Paris, v. 17, n. 2, 159-168, 1986.

DIAS, L. S.; SANTARÉM, V. A.; ALMEIDA, M. S. R.; MEDINA, A. O.; SILVA, A. V. da. Biodiversidade de moscas Calliphoridae no lixão urbano de Presidente Prudente, São Paulo, Brasil. Arquivo do Instituto Biológico, São Paulo, v. 76, n. 4, p. 659-663, 2009.

DUFOUR, S.; DOHOO, I. R.; BARKEMA, H. W.; DESCÔTEAUX, L.; DEVRIES, T. J.; REYHER, K. K.; ROY, J. P.; SCHOLL, D. T. Epidemiology of coagulasenegative staphylococci intramammary infection in dairy cattle and the effect of bacteriological culture misclassification. Journal of dairy science, Champaign, v. 95 , n. 6, p. 3110-3124, 2012.

EESA, N. M.; EL-SIBAE, M. M. Population dynamics of some synanthropic fly species in different habitats in Buraydah, Saudi Arabia. Journal of the Egyptian Society of Parasitology, Cairo, v. 23, n. 1, p. 133-140, 1993.

FERREIRA, M. J. M.; LACERDA, P. V. Muscóides sinantrópicos associados ao lixo urbano em Goiânia, Goiás. Revista Brasileira de Zoologia, Curitiba, v. 10, n. 2, p. 185-195, 1993.

FÖRSTER, M.; SIEVERT, K.; MESSLER, S.; KLIMPEL, S.; PFEFFER, K. Comprehensive study on the occurrence and distribution of pathogenic microorganisms carried by synanthropic flies caught at different rural locations in Germany. Journal of Medical Entomology, Honolulu, v. 46, n. 5, p. 1164-1666, 2009.

GERRY, A. C.; HIGGINBOTHAM, G. E.; PERIERA, L. N.; LAM, A.; SHELTON, C. R. Evaluation of surveillance methods for monitoring house fly abundance and activity on large commercial dairy operations. Journal of economic entomology, College Park, v. 104, n. 3, p. 1093-1102, 2011.

GRACZYK, T. K.; KNIGHT, R.; GILMAN, R. H.; CRANFIELD, M. R. The role of non-biting flies in the epidemiology of human infectious diseases. Microbes and Infection, Paris, v. 3, n. 3, p. 231-235, 2001.
HOGSETTE, J. A.; URECH, R.; GREEN, P. E.; SKERMAN, A.; ELSON-HARRIS, M. M.; BRIGHT, R. L.; BROWN, G. W. Nuisance flies on Australian cattle feedlots: immature populations. Medical and veterinary entomology, Boston, v. 26, n. 1, p. 46-55, 2012.

HOLT, P. S.; GEDEN, C. J.; MOORE, R. W.; GAST, R. K. Isolation of Salmonella enterica serovar Enteritidis from houseflies (Musca domestica) found in rooms containing Salmonella serovar Enteritidis-challenged hens. Applied and Environmental Microbiology, Washington, v. 73, n. 19, p. 6030-6035, 2007.

LEVINE, O. S.; LEVINE, M. M. Houseflies (Musca domestica) as mechanical vectors of shigellosis. Reviews of Infectious Diseases, Chicago, v. 13, n. 4, p. 688-696, 1991.

MACEDO, R. S.; CARRARO, V. M.; ESPINDOLA, C. B.; CABRAL, M. O. Ocorrência de Dípteros Muscóides (Calliphoridae) no Município de Vassouras, RJ. Revista Eletrônica TECCEN, Vassouras, v. 4, n. 1, p. 5-16, 2011.

MOHLER, V. L.; IZZO, M. M.; HOUSE, J. K. Salmonella in calves. Veterinary Clinics of North América: Food Animal Practice, Philadelphia, v. 25, n. 1, p. 37-54, 2009.

MOON, R. D.; HINTON, J. L.; O'ROURKE, S. D.; SCHMIDT, D. R. Nutritional value of fresh and composted poultry manure for house fly (Diptera: Muscidae) larvae. Journal of Economic Entomology, College Park, v. 94, n. 5, p. 1308-1317, 2001.

MURRAY, P. R.; BARON, E. J.; JORGENSEN, J. H.; PFALLER, M. A.; YOLKEN, R. H. Manual of clinical of microbiology. $8^{\text {th }}$ ed. St. Louis, Missouri: ASM Pr, 2003. $2113 \mathrm{p}$.

NAYDUCH, D.; CHO, H.; JOYNER, C. Staphylococcus aureus in the house fly: temporospatial fate of bacteria and expression of the antimicrobial peptide defensin. Journal of medical entomology, Honolulu, v. 50, n. 1, p. 171-178, 2013.

NCCLS. Performance standards for antimicrobial susceptibility testing; fittenth informational supplement. CLSI document M 100-S 15. 15. ed. Pennsylvania:, Clinical and Laboratory Standards Institute, 2005. p. 177. p.

OLIVER, S. P.; GILLESPIE, B. E.; HEADRICK, S. J.; LEWIS, M. J.; DOWLEN, H. H. Prevalence, risk factors, and strategies for controlling mastitis in heifers during the periparturient period. International Journal of Applied Research in Veterinary Medicine, Newtown, v. 3, n. 2, p. 150-162, 2005.

PAGANO, M.; GAUVREAU, K. Principios de bioestatística. 2. ed. São Paulo: Pioneira Thomson Learneing, 2004. 506 p. 
PARALUPPI, N. D.; CASTELLÓN, E. G. Calliphoridae (Diptera) em Manaus: I levantamento taxonômico e sazonalidade. Revista Brasileira de Entomologia, São Paulo, v. 38, n. 3-4, p. 661-668, 1994.

PRADHAN, A. K.; VAN KESSEL, J. S.; KARNS, J. S.; WOLFGANG, D.R.; HOVINGH, E.; NELEN, K. A.; SMITH, J. M.; WHITLOCK, R. H.; FYOCK, T.; LADELY, S.; FEDORKA-CRAY, P. J.; SCHUKKEN. Y. $H$. Dynamics of endemic infectious diseases of animal and human importance on three dairy herds in the northeastern United States. Journal of Dairy Science, Champaign, v. 92, n. 4, p. 1811-1825, 2009.

QUINTO, E. J.; CEPEDA, A. Incidence of toxigenic Escherichia coli in soft cheese made with raw or pasteurized milk. Letters in Applied Microbiology, Oxford, v. 24, n. 4, p. 291-295, 1997.

RAHUMA, N.; GHENGHESH, K. S.; BEN AISSA, R.; ELAMAARI, A. Carriage by the housefly (Musca domestica) of multiple-antibiotic-resistant bacteria that are potentially pathogenic to humans, in hospital and other urban environments in Misurata, Libya. Annals of Tropical Medicine and Parasitology, Liverpool, v. 99, n. 8, p. 795-802, 2005.
REIS, S. F.; TEIXEIRA, M. A.; VON ZUBEN, F. J.; GODOY, W. A.; VON ZUBEN, C. J. Theoretical dynamics of experimental populations of introduced and native blowflies (Diptera:Calliphoridae). Journal of medical entomology, Honolulu, v. 33, n. 4, p. 537-544, 1996.

SAWANT, A. A.; HEGDE, N. V.; STRALEY, B. A.; DONALDSON, S. C.; LOVE, B. C.; KNABEL, S. J.; JAYARAO, B. M. Antimicrobial-resistant enteric bacteria from dairy cattle. Applied and environmental microbiology, Washington, v. 73, n. 1, p. 156-163, 2007.

SCHUSTER, G. L.; DONALDSON, J. R.; BUNTYN, J. O.; DUOSS, H. A.; CALLAWAY, T. R.; CARROLL, J. A.; FALKENBERG, S.M.; SCHMIDT, T. B. Use of bioluminescent Escherichia coli to determine retention during the life cycle of the housefly, Musca domestica (Diptera: Muscidae, L). Foodborne pathogens and disease, Larchmont, v. 10, n. 5, p. 442-447, 2013.

SILVA, E. R. da; SILVA, N. da. Coagulase gene typing of Staphylococcus aureus isolated from cows with mastitis in southeastern Brazil. Canadian Journal of Veterinary Research, Ottawa v. 69, n. 4, p. 260-264, 2005.

TURNIDGE, J. Antibiotic use in animals-prejudices, perceptions and realities. The Journal of antimicrobial chemotherapy, London, v. 53, n. 1, p. 26-27, 2004. 
